\section{International Attendees}

Please be sure to check with your local embassy or consulate regarding the required travel documents for visiting Canada.

For more information, please visit: www.cbsa.gc.ca and www.cic.gc.ca.

If you require a letter of invitation from the AATS, please visit www.aats.org.

For more information, please visit www.aats.org/annual meeting.

\section{AATS Awards Applications}

\begin{abstract}
AATS Evarts A. Graham Memorial Traveling Fellowship Now accepting applications—July 1st Deadline

The AATS Graham Memorial Traveling Fellowship provides a one year opportunity for promising young academic cardiothoracic surgeons from outside the region to attend a North American institution to broaden their overall training and increase their international contacts. The selected Fellow will receive a stipend of $\$ 75,000$ USD to support studies at a primary center of their choice as well as travel to secondary sites in North America. Since the inception of the Graham Traveling Fellowship, 60 individuals from 30 countries have completed the Fellowship.
\end{abstract}

For more information or to apply, please visit the AATS Web site at www.aats.org.

AATS Third Alton Ochsner Research Scholar Research Scholarship, 2015-2017

Now accepting applications-July 1st Deadline

The AATS Third Alton Ochsner Research Scholarship provides an opportunity for research, training, and experience for North American surgeons committed to pursuing an academic career in cardiothoracic surgery. The duration of the scholarship is to be two years and applications must be submitted during the candidates' first two years in an academic position.

The yearly stipend for this scholarship shall be $\$ 80,000$ that will be paid to the host institution for support of salary, research supplies, travel, and other legitimate academic expenses of the scholar. The stipend is to be used for direct salary support and related research expenses only.

For more information or to apply, please visit the AATS Web site at www.aats.org.

\section{New in 2014-Save the Date}

\section{AATS Cardiovascular Valve Symposium \\ September 4-6, 2014 \\ Hilton Istanbul, Istanbul, Turkey}

\section{Program Directors}

\section{David H. Adams}

Mount Sinai School of Medicine

New York, New York, USA

\section{Sertac Cicek}

Anadolu Medical Center

Istanbul, Turkey

Joseph S. Coselli

Baylor College of Medicine

Houston, Texas, USA

Pedro J. del Nido

Children's Hospital

Boston, Massachusetts, USA

For more information, visit www.aats.org/valveistanbul

\section{The American Association for Thoracic Surgery Journals}

\section{Seminars in Thoracic and Cardiovascular Surgery}

The Editors of Seminars in Thoracic and Cardiovascular Surgery want to call your attention to a couple of pieces in the Fall 2013 issue. The first is the expert roundtable on "Discussions in Cardiothoracic Treatment and Care: Management of the Apical Tumor." This hot topic features a spirited conversation between noted experts Drs Manjit Bains, Stephen Swisher, and Eric Vallières, moderated by
Dr Jessica Donington. During this nearly two-hour-long discussion, views on topics such as timing, institutional protocols, palliation of pain, and outcomes are compared between authorities in the field. For an excerpt and more highlights from this discussion, please go here: http:// www.semthorcardiovascsurg.com.

The Editors would also like to make mention of the article, "Current Status of TAVR" by Drs Robert Bonow, Lars Svensson, and Eric Roselli. The article discusses patient selection in the PARTNER trial and important indications for and improvements expected following TAVR. The "Current Status of TAVR" is in the News and Views section of the Fall 2013 issue. 